\title{
Comprehensive review of oncological emergencies seen in clinical practice
}

\section{Kompleksowy przegląd nagłych przypadków onkologicznych w praktyce klinicznej}

\author{
Paul Oben ${ }^{1}$, Vincent Fein ${ }^{2}$ \\ 'Department of Internal Medicine, University of Chicago, IL, USA \\ 2Department of Internal Medicine, Mercy Hospital and Medical Center, Chicago, IL, USA
}

Medical Studies/Studia Medyczne 2019; 35 (1): 69-81

DOI: https://doi.org/10.5114/ms.2019.84054

Key words: oncology, febrile neutropaenia, emergencies, tumour lysis syndrome, leukostasis.

Słowa kluczowe: onkologia, gorączka neutropeniczna, nagłe przypadki, zespół rozpadu guza, leukostaza.

\begin{abstract}
Aim of the research: To provide an up-to-date review of the literature on the pathophysiology, diagnosis, and management of common oncologic emergencies encountered in clinical practice.

Material and methods: We conducted a systematic computerised search in PubMed, Scopus, Web of Science, and Embase. Results: We reviewed relevant medical literature. Most common complications requiring emergency management are addressed in this review, specifically: tumour lysis syndrome, seizures and status epilepticus, pulmonary embolism, leukostasis, thrombotic microangiopathy, febrile neutropaenia, disseminated intravascular coagulation, massive haemoptysis, diffuse alveolar haemorrhage, stem cell transplant-related complications, surgically related complications of malignancy, metastatic spinal cord metastasis, and superior vena cava syndrome.

Conclusions: Oncologic emergencies and related complications demand increased attention from attending physicians, oncologists, and intensivists. Knowledge of oncologic emergencies encountered in clinical practice expedites the ability of physicians to manage them properly. The identification and institution of proper management can improve outcomes in these patients.
\end{abstract}

\section{Streszczenie}

Cel pracy: Przegląd aktualnego piśmiennictwa na temat patofizjologii, diagnostyki i postępowania w nagłych przypadkach onkologicznych w praktyce klinicznej.

Materiał i metody: Przeprowadzono systematyczne, komputerowe wyszukiwanie przypadków onkologicznych w bazach PubMed, Scopus, Web of Science i Embase.

Wyniki: Dokonano przeglądu odpowiedniej literatury medycznej. W pracy omówiono najczęściej występujące powikłania wymagające pilnego leczenia, takie jak zespół rozpadu guza, napady i stan padaczkowy, zatorowość płucna, leukostaza, mikroangiopatia zakrzepowa, gorączka neutropeniczna, zespół rozsianego wykrzepiania wewnątrznaczyniowego, masywne krwioplucie, rozlane krwawienie pęcherzykowe, powikłania związane z przeszczepem komórek macierzystych, powikłania chirurgiczne związane z nowotworem, przerzuty do rdzenia kręgowego i zespół żyły głównej górnej.

Wnioski: Nagłe przypadki onkologiczne oraz związane z nimi powikłania wymagaja większej uwagi lekarzy prowadzących, onkologów i lekarzy intensywnej terapii. Znajomość nagłych przypadków onkologicznych spotykanych w praktyce klinicznej pozwala na sprawne ich leczenie. Ustalenie oraz wdrożenie właściwego postępowania umożliwia poprawę wyników leczenia tych chorych.

\section{Introduction}

There will be an estimated 18.1 million new cancer cases and 9.6 million cancer deaths in 2018 [1]. As per the Globocan 2018 database, in both sexes combined lung cancer ( $11.6 \%$ of the total cases) is the most commonly diagnosed cancer, followed by breast (11.6\%), prostate (7.1\%), and colon (6.1\%) carcinoma. The leading cause of cancer deaths is lung cancer $(18.4 \%$ of the total cases), followed by stomach (8.2\%) and liver $(8.2 \%)$ cancer [1-3]. Cancer and its therapy may lead to medical conditions, some of which might be emergent. The care of oncologic patients with emergencies presents a challenge not only to medical oncologists but also to clinicians involved in their care. An oncological emergency is defined as an acute condition that is caused by cancer or its treatment, requiring 


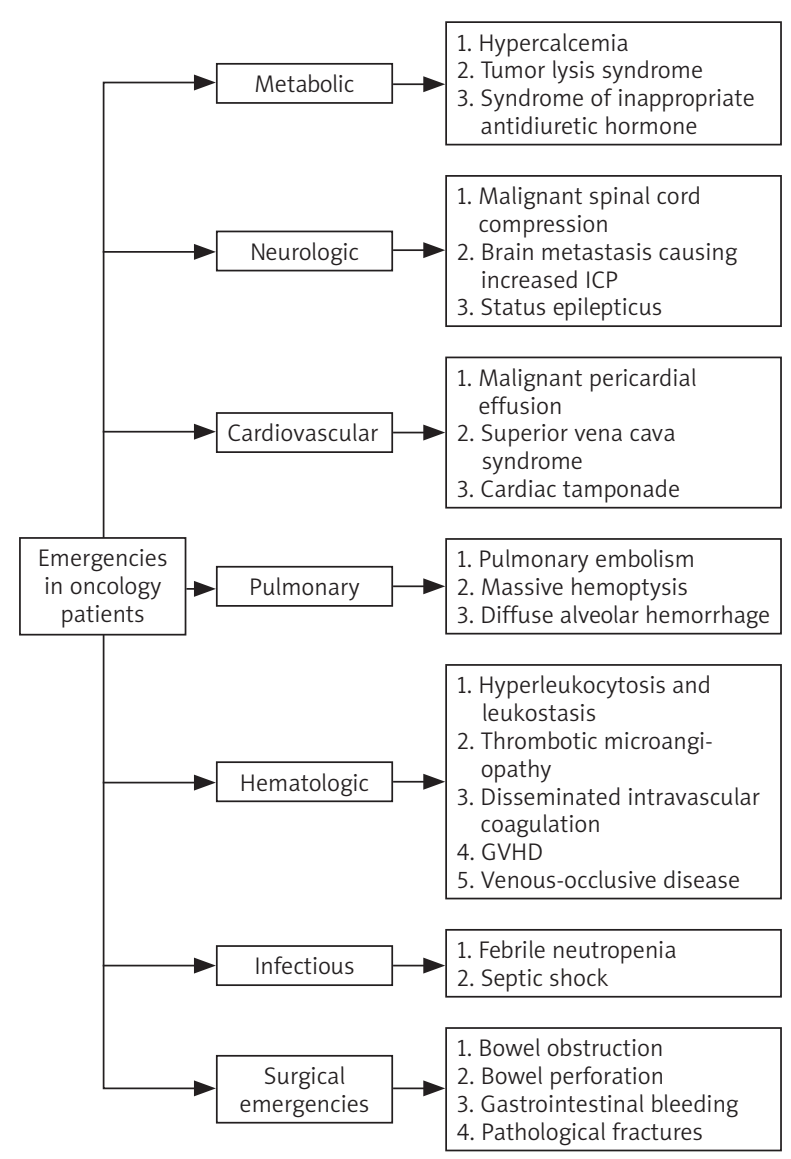

Figure 1. Oncologic emergencies seen in clinical practice

rapid intervention to avoid death or severe permanent damage.

Most common complications requiring emergency management are addressed in this review (Figure 1), specifically: tumour lysis syndrome, seizures and status epilepticus, pulmonary embolism, leukostasis, thrombotic microangiopathy, febrile neutropenia, disseminated intravascular coagulation, massive haemoptysis, diffuse alveolar haemorrhage, stem cell transplant-related complications, surgically related complications of malignancy, metastatic spinal cord metastasis, and superior vena cava syndrome [4].

\section{Methods}

We conducted a systematic computerised search in PubMed, Scopus, Web of Science, and Embase. We reviewed relevant medical literature.

\section{Oncologic emergencies}

\section{Tumour lysis syndrome}

Tumour lysis syndrome (TLS) comprises a group of metabolic abnormalities that occur as a complication secondary to lysis of tumour cells, thereby releasing their cellular content. It usually occurs due to cytotoxic chemotherapy but can also occur spontaneously in highly proliferative tumours due to increased cell turnover. It is mostly reported in patients with high-grade non-Hodgkin lymphomas (NHL) and acute leukaemias, but it can occur in any cancer mass that is large and chemosensitive [5]. The TLS is classified as laboratory or clinical TLS according to the classification system of Cairo and Bishop. Laboratory TLS is the presence of two or more of the metabolic abnormalities like hyperuricaemia (uric acid $\geq 476 \mu \mathrm{mol} / 1$ $(8 \mathrm{mg} / \mathrm{dl})$ ), hyperkalaemia (potassium $\geq 6.0 \mathrm{mmol} / \mathrm{l}$ ), hyperphosphataemia (phosphorus $\geq 1.5 \mathrm{mmol} / 1$ $(4.5 \mathrm{mg} / \mathrm{dl})$ in adults or $\geq 2.1 \mathrm{mmol} / 1(6.5 \mathrm{mg} / \mathrm{dl})$ in children) and hypocalcaemia (calcium $\leq 1.75 \mathrm{mmol} / 1$ (7 mg/dl) or ionised calcium $<0.3 \mathrm{mmol} / \mathrm{l}(1.12 \mathrm{mg} / \mathrm{dl}))$ occurring within the 3 days before initiation of therapy or seven days after initiation of treatment, assuming that the patient receives adequate hydration and a hypouricemic agent [6]. On the other hand, clinical TLS is defined as the presence of laboratory TLS along with either acute kidney injury (AKI) (increase in creatinine of $26.5 \mu \mathrm{mol} / 1(0.3 \mathrm{mg} / \mathrm{dl})$ from baseline) or when no baseline is available, a single value $\geq 1.5$ times the upper limit of normal for the patient's age and sex or symptomatic hypocalcaemia like tetany and paraesthesia, seizures, cardiac dysrhythmias, and sudden death attributed to hypocalcaemia or hyperkalaemia [6].

The pathophysiological events are attributed mainly to the release of cellular components in the bloodstream. The catabolism of purines produces uric acid by xanthine oxidase. Increased breakdown of nucleic acids, in turn, produces a large amount of uric acid, which becomes crystallised in renal tubules resulting in AKI. This is further worsened by hyperphosphataemia, which is deposited in the renal tubules as calcium phosphate, which in turn leads to hypocalcaemia. Hyperkalaemia is due to cell lysis and release of intracellular potassium [7]. The symptoms of TLS are not specific, and they largely depend on the underlying metabolic abnormalities and those related to AKI [8].

Management of TLS involves risk stratification and management based on the risk, the goal of which is to prevent clinical TLS because it is associated with morbidity. The American Society of Clinical Oncology stratifies them into high, intermediate, and low risk based on the type of cancer, leucocyte count, and rapidity of proliferation with the expected response to chemotherapy $[9,10]$. Low-risk patients should be monitored clinically and be educated about how to keep themselves adequately hydrated. Intermediaterisk patients should be rehydrated along with initial management of daily dose of allopurinol, a xanthine oxidase inhibitor. Rasburicase, which is a recombinant version of urate oxidase, metabolising insoluble uric acid to allantoin, may be considered if hyperuricaemia develops, or as initial management in paedi- 
atric patients. In the case of patients with established TLS or high risk for TLS, vigorous hydration except in cases of AKI and followed by initial management with rasburicase [9]. The coexisting metabolic abnormalities are treated accordingly.

\section{Seizures and status epilepticus}

Seizures in oncology patients may be a result of primary brain neoplasm or secondary brain metastasis. However, there are also other reasons apart from tumours, namely electrolyte imbalance, infections, brain haemorrhage, TLS, liver/renal failure, and cytotoxic drug toxicity [11]. The anticancer drugs that are thought to cause seizures include the following: cytarabine, methotrexate, cisplatin, etoposide, vincristine, cyclophosphamide, ifosfamide, nitrosoureas, and anthracyclines [11]. The incidence of seizures in systemic cancer is $5 \%$, but for patients with an intracranial neoplasm, the incidence increases to nearly 30\% [12]. The type of seizures that predominate in this population is partial in onset, with or without secondary generalization. The goals of treatment are two-fold, the first being control of systemic or intracranial neoplasm, which is followed by control of seizures [13] For patients with systemic neoplasm the only available option is anti-epileptics (AEDs), whereas patients with primary brain neoplasm can undergo chemotherapy, radiotherapy, surgery, and AEDs [13]. Whenever a reversible aetiology such as a metabolic disorder is suspected, it should be diagnosed and treated promptly. However, it should be noted that patients with brain metastases, who have not had the first seizure, do not benefit from prophylactic administration of AED. A Cochrane review also concluded that there was no significant difference between placebo and treatment with phenobarbital, phenytoin, or valproic acid in preventing the first seizure [14].

Seizures are usually self-limiting but can evolve into a status epilepticus, wherein cortical injury occurs after 20 to $30 \mathrm{~min}$ of seizure activity. By definition, it is called a status epilepticus if a single continuous seizure lasts longer than 5 min or two or more seizures occur without returning to the baseline between the events [15]. Seizures can also be nonconvulsive if the patient initially starts with a convulsion followed by subtle ongoing seizure activity, such as muscle twitch or deviation of the eye, with a mental disturbance, which lead to the conclusion that the patient is in the post-ictal phase [16]. This type of status is challenging to diagnose unless with the help of an electroencephalogram. The mainstay of treatment is with parenteral benzodiazepines, and the second-line agent is phenytoin or its prodrug fosphenytoin [17]. Although the management of nonconvulsive status epilepticus is on similar lines, it is difficult to devise an algorithm due to lack of data on aggressive management improving the clinical out- come [15]. Unlike in the normal population, where medical non-adherence is the usual cause for status epilepticus, in cancer patients a thorough evaluation should be done to rule out electrolyte imbalance and structural causes of the mass effect, haemorrhage, worsening oedema, or necrosis. In case of mass effect or edema as the cause of seizures, administration of dexamethasone may be highly effective in the management of seizures $[18,19]$.

\section{Pericardial effusion and cardiac tamponade}

Collection of fluid in the pericardial space is called pericardial effusion. The pericardial sac is usually distensible for up to 21 if the accumulation occurs slowly over a long time [20]. As the intra-pericardial pressure accumulates, it prevents the distension of all the four chambers of the heart but more so of the right ventricle as it is thinnest. The venous return is hampered, resulting in a compromised filling, and the diastolic pressures tend to equalise and subsequently affect the cardiac output. At this point, a tamponade develops. Tamponade physiology can arise with just $100 \mathrm{ml}$ if the accumulation is acute [21]. The cardiac tamponade classically presents as Beck's triad - hypotension, elevated jugular venous pressure (JVP), and muffled precordium. However, this classic triad may not be seen when the accumulation is gradual, and these patients usually present with just chest discomfort or breathing difficulties [22]. Pericardial effusion in oncologic patients is either due to metastasis or through the direct extension of a tumour. Metastasis of the epicardium is from non-contiguous breast or lung cancer and melanoma. Primary neoplasms of the pericardium are extremely rare [4].

Diagnosis of pericardial effusion is through clinical examination coupled with specific confirmatory investigations [4]. Clinically there is tachycardia, pulsus paradoxus, elevated JVP, and muffled heart sounds. An X-ray may show the water bottle appearance of cardiac silhouette. Electrocardiogram (ECG) shows low voltage, and electrical alterations as the heart pendulates within the distended sac [4].

The mainstay of treatment is pericardiocentesis. This is usually done with sonographic guidance, and blinded subxiphoid pericardiocentesis is more prone to complications and hence is reserved as a last resort. A catheter can also be placed if recurrence of fluid collection is anticipated. In the case of adenocarcinoma, which is proof for recurrence, a pericardial window or pericardiectomy may be considered [23]. However, close monitoring of the patient is warranted because there is a risk of paradoxical haemodynamic instability, which is directly proportional to the amount of fluid tapped [24]. Installation of chemotherapy for malignant tumours directly into the pericardial sac is another potential procedure that needs further exploration $[25,26]$. 


\section{Leukostasis}

Leukostasis or symptomatic hyperleukocytosis is an extreme form of leucocytosis that is defined by white blood cell (WBC) count greater than 100,000 cells/ $\mathrm{mm}^{3}$. This is most commonly seen in patients with haematological malignancies, especially in acute myeloid (AML) and lymphoid leukaemia (ALL). It can also be seen during chronic myeloid leukaemia (CML) during the blast crisis [27]. This excess WBCs can clump together and block the microcirculation to end organs leading to hypoxemia or haemorrhagic manifestations. The most common organ systems affected are the lungs and the brain [28]. Therefore, the symptoms depend mainly on the organ system affected, but usually they present with dyspnoea or CNS symptoms like headache, vomiting, blurred vision, seizures, delirium, coma, ataxia, etc. [29]. The total WBC count is also a prognostic factor wherein a common arbitrary

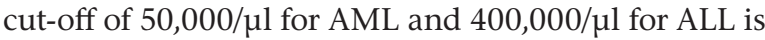
considered as the blasts are much larger than the lymphocytes [30].

The pathophysiology of leukostasis is not clearly understood. However, two possible theories have been put forward. The first one being the traditional rheological theory of hyperviscosity, which largely depends on the deformability of the cells and the volume of cell fraction in the blood. The blast cells are less deformable than leukocytes, and a similarly increased cell fraction increases the viscosity of the blood, thereby "sludging" the flow in the vessels [27]. The second theory is that the endothelial cells are activated by the blast cells, which secrete inflammatory cytokines. There is also an adhesive interaction between the endothelial cells and the blasts, thereby precipitating the leukostasis [27].

The clinical diagnosis is based on the blood counts and peripheral smear along with the clinical presentation of end-organ hypoxaemia or haemorrhage. A chest $\mathrm{X}$-ray or computed tomography (CT) of the chest usually shows bilateral interstitial or alveolar infiltrates. The CT or magnetic resonance imaging (MRI) of the brain may reveal intracranial haemorrhagic manifestations [29]. One must also be on the look-out for TLS and should obtain the acid-base and electrolyte status of the patient along with renal function tests as soon as possible [28]. The initial treatment for at-risk patients consists mainly of aggressive rehydration with calcium and potassium free fluids and prevention of TLS by prescribing allopurinol or rasburicase, as well as ensuring adequate hydration and the correction of underlying metabolic abnormalities. The definitive management, however, consists of chemotherapy to decrease the tumour load [28]. In the case of patients with very

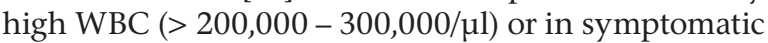
patients, leukapheresis is the treatment of choice [31] A single leukapheresis depletes the blood of $20-50 \%$ of WBC, which is then re-infused into the patient [32]. In patients where there is severe anaemia and impending congestive cardiac failure, exchange transfusion may be considered. The partial exchange helps in correcting hyperleukocytosis and severe anaemia without increasing the viscosity and fluid overload, which are the main drawbacks of whole blood transfusion and hydration, respectively [28]. Finally, monitoring of vital signs, clinical symptoms, and lab parameters including an acid-base and electrolyte balance forms an essential aspect of management of leukostasis [28]. Hydroxyurea is typically used for patients with asymptomatic hyperleukocytosis, who are unable to receive immediate induction chemotherapy [33].

\section{Disseminated intravascular coagulation}

Disseminated intravascular coagulation (DIC) is a pathological condition in which there is excessive production of thrombin, which in turn causes consumptive coagulopathy leading to the consumption of fibrinogen and other coagulative proteins, resulting in the production of fibrin thrombi [34]. In malignancy, there are two primary mechanisms by which DIC is initiated, namely tissue injury or endothelial cell alteration. Endothelial cell alteration is predominantly seen in infectious diseases where there is kallikrein-kinin activation, and as we are aware, infection is not uncommon in malignancy. Secondly, tissue injury also occurs in malignant tumours in which procoagulant material like the tissue factor is expressed on circulating tumour cells or on the surface of the vessel walls [35]. No single laboratory test can rule in or rule out DIC. A battery of tests like platelet counts, fibrin degradation products, D-dimer, fibrinogen, prothrombin, and activated partial thromboplastin time along with clinical features are indispensable in obtaining a diagnosis of DIC. A major principle in the management of DIC is to treat the underlying causes in order to eliminate the stimulus for ongoing coagulation and thrombosis. The primary goal of treatment is to replace the consumed blood components like platelets, fresh frozen plasma, cryoprecipitate, and fibrinogen concentrate. Transfusion of platelets or plasma components should be considered only in patients with overt manifestations or at high risk for symptoms and should not be given prophylactically to a non-symptomatic patient $[36,37]$. The UFH infusion is considered in patients in whom features of thrombosis predominate rather than a bleeding tendency. Evidence on the use of activated protein $\mathrm{C}$ is lacking, and therefore it cannot be recommended for routine antithrombin use. Similarly, antifibrinolytics should never be given to patients with DIC [36].

\section{Thrombotic microangiopathy}

Thrombotic microangiopathies (TMAs) comprise a group of disorders that includes disseminated microvascular occlusive thrombosis, thrombocytopaenia, and ischaemic end-organ damage. The two main 
subtypes include haemolytic uremic syndrome (HUS) and thrombotic thrombocytopaenic purpura (TTP). The TTP encompasses a pentad of clinical findings, namely: thrombocytopaenia, microangiopathic haemolytic anaemia (MAHA), neurologic deficits, renal failure, and fever. The HUS refers to the triad of MAHA, thrombocytopaenia, and renal failure [38]. The pathophysiology is of intra-renal or systemic microvascular thrombi with endothelial swelling and microvascular obstruction. As the erythrocytes pass through the narrowed arterioles, they become fragmented and give rise to Coombs-negative haemolytic anaemia [39]. The aetiology of TMA may be due to the manifestation of cancer itself, as a complication of chemotherapy either via an immune-mediated reaction or dose-dependent toxicity, in the setting of bone marrow transplantation, and finally in those receiving antibodies and immunotoxins [38]. The diagnosis of TMA is based on recognising the microvascular thrombosis, red blood cell destruction, and consumption of platelets [39]. At present, there are no definitive approaches to cancerassociated TMA. When a given regime is thought to be causative, withholding the implicated drug is beneficial. Introducing at a lower dose may be tried while allowing for continued treatment [38]. The role of immunosuppressive therapies like glucocorticoids is uncertain. Similarly, immunocomplex removal techniques like plasmapheresis, immunoadsorption, haemodialysis, or exchange transfusion may be utilised but may need continued therapy for months [40]. Eculizumab, which is a recombinant humanised monoclonal antibody binding to complement C5 protein inhibiting its cleavage and preventing generation of terminal complement attack complex C5b-9, is under consideration for use in atypical HUS [38].

\section{Febrile neutropaenia}

Neutropaenia is usually defined as an absolute neutrophil count (ANC) of less than $1500 / \mu 1$, and severe neutropaenia is defined as ANC $<500 / \mu 1$. Febrile neutropaenia is defined as a single oral temperature of $\geq 38.3^{\circ} \mathrm{C}(101 \mathrm{~F})$ sustained for $1 \mathrm{~h} \mathrm{[41]}$. The reason for a decrease in the ANC is mainly due to the adverse effect of cytotoxic chemotherapy. Some of the other reasons are tumour infiltration of bone marrow or direct interference with haematopoiesis, as in the case of haematological malignancies [42]. The significant risk factors include the rate of decline of ANC, previous exposure to chemotherapy, current immunosuppression, elevated liver enzymes pre-treatment, reduced glomerular filtration rate, and cardiovascular co-morbidities. On the other hand, there are different classes of cytotoxic drugs that have the highest risk of inducing neutropaenia; namely, the anthracyclines, taxanes, topoisomerase inhibitors, platinum, gemcitabine, vinorelbine, and certain alkylators like cyclophosphamide and ifosfamide [43]. The anti- microbial agent causing fever is identified only in a minority of patients, and in the rest it is thought to be caused by a variety of organisms. The common causative organism is one of the gram-positive cocci; namely, Staphylococcus aureus, Staphylococcus epidermidis, Streptococcus pneumoniae, Streptococcus pyogenes, Streptococci viridans, and Enterococcus faecalis and faecium [44]. However, the antimicrobial spectrum also includes Gram-positive bacillus mainly the Corynebacterium, Gram-negative bacterium like Escherichia coli, Klebsiella and Pseudomonas aeroginosa, and fungal agent candida species [45]. The evaluation is similar to what would be done in a patient with pyrexia of unknown origin, except for the fact that the source of infection is aggressively sought because the condition of febrile neutropaenia patients can deteriorate rapidly [41]. Management primarily involves antibiotic therapy, which is started empirically and then tailored accordingly when the drug susceptibility data are made available. When the patient is discharged for outpatient treatment, monitoring is necessary every day. If fever persists for more than $48 \mathrm{~h}$, the patient should be hospitalised [41, 46]. Antibiotic therapy should be continued until ANC is above $500 / \mu 1$. The addition of an antifungal agent is considered when fever persists despite 4-7 days of broad-spectrum antibiotics with no identified causative organism [41]. In the case of a documented IV catheter-related infection, the indwelling catheter need not be removed if the isolated organism is coagulase-negative for Staphylococcus [47]. However, in cases of Staphylococcus aureus, Pseudomonas aeroginosa, fungi, or mycobacteria, the catheter is removed and the antimicrobial is continued for at least 2 weeks [47]. An upcoming therapy is the use of colony stimulating factors (CSF) in patients with neutropaenia. The American Society of Clinical Oncology does not recommend the routine use of CSFs unless the anticipated risk of febrile neutropaenia is $20 \%$ or greater and when no other safe and equally effective alternatives are available $[47,48]$.

\section{Pulmonary embolism}

Pulmonary embolism (PE) is a fatal condition in which emboli, usually originating from a thrombus usually in the deep veins of the legs or pelvis, blocks one or more pulmonary arteries thus causing impaired blood flow and increased pressure in the right cardiac ventricle. Symptomatic venous thromboembolism occurs in 1-2 per 1000 adults each year, with about a third presenting with PE [49]. Some of the risk factors include age, previous thromboembolism, malignancy, coagulation disorders, and oral contraception $[50,51]$. The risk of developing symptomatic $\mathrm{PE}$ is sevenfold higher in patients with cancer than in those without, and approximately 10\% of all PEs are secondary to known cancer [52]. 
The PE cannot be diagnosed or excluded on clinical grounds because the symptoms and signs are nonspecific [53]. However, it has long been recognised that unexplained dyspnoea and chest pain are present in about $97 \%$ of patients with proven PE, which raises the suspicion of $\mathrm{PE}$ and selection of patients for further diagnostic testing [54]. Patients with PE (> 85\%) tend to complain primarily of sudden-onset or worsened resting dyspnoea [55]. Other presentations of PE can include chest pain - usually sharp, a cough (approximately $20 \%$ of patients), haemoptysis as a consequence of lung infarction (7\%), and syncope (14\%) [52]. The PE can be categorised into low-risk, moderate, and massive, which readily correlates with increasing levels of mortality. Massive PE is characterised by cardiovascular collapse. Sub-massive PE, on the other hand, involves stable patients with evidence of right ventricular strain due to increased wall tension [56].

The diagnosis of PE is based on the assessment of clinical likelihood, electrocardiography (ECG), echocardiography, chest X-ray (CXR), and imaging techniques such as computed tomographic pulmonary angiography or ventilation-perfusion scintigraphy [57]. ECG changes indicate right ventricle strain such as T-wave inversion in leads V1-V4, QR pattern in V1, and S1Q3T3 pattern and incomplete or complete right bundle branch block. It may also be associated with atrial arrhythmias, most commonly atrial fibrillation - in $40 \%$ of patients [55]. Echocardiography thus detects the right ventricular pressure overload and dysfunction. Elevation of plasma D-dimer levels representing acute thrombosis is not considered as a confirmatory test for PE because fibrin, which influences $\mathrm{D}$-dimer levels, is also increased in a lot of other conditions like cancer, inflammation, bleeding, trauma, and surgery [55]. Although pulmonary angiography has remained the gold standard for the diagnosis of $\mathrm{PE}$, less invasive CT-angiography is preferred because it offers similar diagnostic accuracy. Digital subtraction angiography (DSA) is another modality, which uses less contrast and can be used to detect peripheral pulmonary vessel embolism. The presence of thrombus is diagnosed on CT-angiography as a filling defect or as amputation of the pulmonary arterial branch. Magnetic resonance angiography is an upcoming but less studied modality, which is yet to be considered for regular clinical use in PE diagnostics [55].

Treatment options include management during the acute phase, both medical and surgical, which is followed by extended management. In the acute phase, haemodynamic and respiratory support is provided mandatorily. This may also necessitate the use of vasopressors. This is followed by the use of anticoagulants to prevent early death and recurrent thromboembolism [50]. The standard duration of therapy is usually 3 months, which includes 5-10 days of parenteral anti-coagulation such as unfractionated heparin
(UFH), low molecular weight heparin (LMWH), or fondaparinux [55]. Parenteral heparin should overlap with the initiation of vitamin K antagonist or one of the newer anticoagulants like dabigatran. If rivaroxaban or apixaban is given, oral treatment should be started directly or after 1-2 days of administration of UFH, LMWH, or fondaparinux [55]. The duration of anticoagulation treatment is extended if there is an underlying risk factor such as an ongoing malignancy [55]. Recombinant tissue-type plasminogen activator (alteplase) and other thrombolytic agents have been used via peripheral infusion in patients who are haemodynamically unstable and have no other contraindications to thrombolytic agents. The surgical options include surgical embolectomy, percutaneous catheter-directed treatment with the help of interventional radiologists, and placement of venous filters in the inferior vena cava [57]. Treatment of massive PE involves both medical and surgical management, as outlined above, and that of low-risk PE involves predominantly medical management [56]. However, the management of sub-massive $\mathrm{PE}$ requires consideration from the treating team on the choice of therapy, and it is not as clear-cut as in major or low-risk PE. Adequate treatment of the underlying malignancy and prompt rehabilitation is indispensable [56].

\section{Massive haemoptysis and diffuse alveolar haemorrhage (DAH)}

Massive haemoptysis is used to describe the expectoration of a large amount of blood and a rapid rate of bleeding, but the precise thresholds that constitute massive haemoptysis are controversial. Thresholds from $100 \mathrm{ml}$ up to $1000 \mathrm{ml}$ over $24 \mathrm{~h}$ have been proposed, but none has been universally accepted [58].

Haemoptysis has multiple causes, usually categorised under parenchymal diseases, airway diseases, and vascular diseases, some of which include bronchitis, bronchiectasis, aspergilloma, tumour, tuberculosis, lung abscess, emboli, coagulopathy, autoimmune disorders, arterio-venous malformation, mitral valve stenosis, and pneumonia [59]. In cases of severe haemoptysis requiring treatment, the source of bleeding originates either from the bronchial artery from the pulmonary arteries. Massive haemoptysis in the case of malignancies results from direct infiltration of the tumour cells into the main blood vessels or due to massive tumour necrosis [60]. Asphyxia due to the flooding of the airways rather than exsanguination is usually the cause of death, and it is commonly accompanied by cardiovascular collapse [61].

Diagnostic modalities for studying haemoptysis include CXR, bronchoscopy, multi-detector computed tomography (MDCT), MDCT angiography (MDCTA), and DSA [51]. Management of patients with haemoptysis is based on the rate and severity of bleeding and the clinical condition of the patient [61]. In unstable 
patients with massive haemoptysis, resuscitation is mandatory before any other diagnostic investigation. An initial CXR is advisable to localise the bleeding site. The MDCTA should be executed in any case, even in an emergency [62]. Surgery remains the treatment of choice only in a few selected cases, such as chest trauma and iatrogenic pulmonary artery rupture [49], while endovascular embolisation is considered the most efficient and minimally invasive procedure for managing massive and recurrent haemoptysis in almost all other cases [62].

Another unique but life-threatening cause of haemoptysis is DAH which can be caused by vasculitis, coagulopathy, inhalational injury, cytotoxic drug therapy, radiation injury, bone marrow transplantation, etc. [63]. It is a distinct clinical-pathological syndrome characterised by pulmonary haemorrhage originating from the pulmonary microvasculature. Besides massive haemoptysis, it presents as diffuse lung infiltration and acute respiratory failure. The confirmatory diagnosis is with the help of a biopsy in which there is an accumulation of erythrocytes, fibrin, or hemosiderin-laden macrophages in the alveolar space [64]. If DAH is associated with an autoimmune condition, the mainstay of treatment is immunosuppressants. However, in most other cases, corticosteroids are the drugs of choice besides other supportive therapy and mechanical ventilation as required for the patient [65].

\section{Surgical emergencies}

Abdominal pain is one of the most frequent presentations of cancer patients in the emergency department. This may arise as a result of the underlying malignancy itself, the treatment directed towards the disease, or the other causes that are seen in an average healthy population $[66,67]$. The main challenge in oncology patients is that they may not have the classic symptoms as seen in normal individuals, like fever and pain, because they have blunted response due to severe immunosuppression [68]. Some of the common abdominal emergencies directly related to the tumour mass include bowel obstruction, perforation, intussusception, and haemorrhage, all of which are treated with emergency laparotomy under broadspectrum antibiotic cover.

\section{Bowel obstruction}

Bowel obstruction may be at the level of the small intestine, large intestine, or gastric outlet obstruction. Similarly, it may be due to mechanical obstruction due to luminal causes, intra-mural or extra-mural causes, and functional obstruction due to mesenteric infiltration or paraneoplastic neuropathy [69]. The symptoms include pain, nausea, vomiting, and abdominal bloating. Complete obstruction can result in constipation or obstipation, but these may be absent when peristalsis below the site of obstruction in the early course of disease may confound these symptoms. The definitive diagnosis is by imaging. An erect and flat radiograph will show dilated bowel loops and air-fluid levels. With the advent of newer modalities like CT and barium meal scans it has become possible to predict the exact level of obstruction in the gastrointestinal system [70, 71].

\section{Perforation}

Bowel obstruction, erosion of primary GI cancers, metastatic lesions to the gut, and certain infections have the potential to cause bowel perforation and peritonitis. These perforations are categorised either as free, when the bowel contents are spilled into the abdominal cavity, or contained, when the contents are walled off by the adjacent intra-abdominal structures. However, in the case of malignancy, $90 \%$ of patients have free perforation because of the inability to localise the infection due to an immunocompromised state [68]. The most common causes of colonic perforations are diverticular disease, ischaemic colitis, faecal impaction, neutropaenic enterocolitis, and opportunistic infections such as cytomegalovirus (CMV) and Candida. Perforations secondary to CMV have also been found in the ileum and jejunum among patients undergoing chemotherapy [72, 73]. An erect radiograph of the abdomen shows air below the diaphragm pointing to the pneumoperitoneum. A CT scan, on the other hand, can pick up small amounts of free air, pneumatosis intestinalis, and portal venous air [74].

\section{Haemorrhage}

Gastrointestinal bleeding (GIB) is another emergency that can be presented by patients with malignancy. It is classified into upper or lower GIB based on the site of bleeding, whether it is proximal or distal to the ligament of Treitz [75]. The causes can be either directly due to a tumour or secondary to serious adverse effects of chemotherapeutic agents. A tumor or metastasis may directly erode into the wall of the gastrointestinal tract. Alternatively, the tumour itself may undergo necrosis and bleeding. Cytotoxic treatment is known to affect all fast-growing living cells in our body and hence directly cause toxic effects on the intestinal mucosa [76]. The presenting symptom is either haematemesis, haematochezia, melena, or occult faecal bleeding, depending on the site and rate of bleeding. For example, a Malory-Weis tear could present as mild haematemesis associated with retching, whereas a variceal bleed secondary to hepatic neoplastic infiltration can present as a haemodynamically unstable massive haematemesis [2, 77]. In any case, a massive upper GIB with impending vascular collapse should prompt initial stabilisation and resuscitation. Investigations like complete blood profile, coagulation panel, biochemistry panel, and 
blood grouping with cross matching are mandatory. Nasogastric aspiration with lavage may help to confirm the source and briskness of the bleed [78-80]. This is followed by the rapid resuscitation with intravenous fluid and blood components like packed erythrocytes, fresh frozen plasma, or cryoprecipitate, as warranted by the laboratory investigations. Also, initial empiric therapy with a proton pump inhibitor is warranted before endoscopy because it neutralises gastric $\mathrm{PH}$ and helps in haemostasis [81]. Endoscopy plays an essential role in diagnosing the site of the lesion and in achieving haemostasis in variceal bleeds. It helps in clipping the bleeding vessels directly, thermo-coagulation, injection sclerotherapy, and balloon tamponade. Transarterial chemoembolisation and open ligation of bleeding vessels are advanced options available to control upper GIB [81, 82]. In the case of lower GIB, colonoscopy proves vital after a cleansing enema. Other modalities available are capsule endoscopy, angiography, and radio-nucleotide imaging. Advanced lesions can be treated with open surgery or radiotherapy [76].

\section{Pathological fractures}

Bone is one of the most frequent organs to be affected due to metastatic spread. Breast and prostate cancer result in $80 \%$ of all secondary bone carcinoma. Bone metastasis is common in the axial skeleton because it has red marrow, and this pattern suggests that capillary structure and sluggish blood flow assist in the development of metastasis [83]. Bone metastasis can cause pain, impaired mobility, hypercalcaemia, pathologic fracture, and spinal cord or nerve root compression. Metastasis in the bone causes a reduction in load-bearing capabilities, resulting initially in trabecular disruption and microfractures and subsequently in a total loss of bony integrity. Rib fractures and vertebral collapse are the commonest, resulting in kyphoscoliosis, height loss, or mild restrictive lung disease [83]. Once a pathologic fracture is confirmed with the help of X-ray or CT, the treatment is mainly surgical, and it depends on the site of the fracture. Bony metastasis per se has to be treated with a multimodal approach involving systemic chemotherapy, hormone therapy, radiotherapy, surgical excision of tumour, and anti-osteoporotic therapy $[83,84]$.

\section{Haematopoietic stem cell transplant (HSCT)-related complications}

Stem cell transplant-related complications can be broadly classified as infectious and non-infectious complications. The post-transplant period is divided into the following: a) pre-engraftment period - less than 30 days after HSCT; b) immediate post-engraftment period (30-100 days); and c) late post-engraftment period (after 100 days) [85]. The risk factors for these infections are mainly due to loss of mucosal in- tegrity, decreased cell-mediated immunity, and other complications like graft versus host disease (GVHD). The infections may be caused due to a large number of bacteria, viruses, fungi, and protozoans [10, 85].

The most common non-infectious complications include GVHD and venous-occlusive disease (VOD). The GVHD is further classified into acute or chronic depending on whether the onset is within 100 days of HSCT or later. The pathophysiology is that since the recipient is immunosuppressed, the graft mounts an immune response against the host. In acute GVHD, the initial presenting complaint is maculopapular rash in the neck, shoulders, ears, palms, and soles [86]. After skin involvement, the next organ system involved is the liver, wherein it may cause serum bilirubin elevation, which is followed by enzymatic elevation [86]. At this stage, it is still not specific enough to make a diagnosis, and an entire set of differential diagnoses of hepatitis should be considered. Subsequently, the gastrointestinal system is involved, resulting in watery diarrhoea and abdominal cramps [87]. The severity is assessed based on the extent of involvement in the skin, liver, and GI tract and an overall grading that has both therapeutic and prognostic implications [86]. Chronic GVHD, on the other hand, starts similarly in the skin but can involve a lot of other systems like lung, mouth, eyes, and joints and resembles more an autoimmune disorder [88]. First-line therapy for GVHD involves systemic corticosteroids followed by antimicrobial prophylaxis, which includes penicillin V, acyclovir, and doublestrength cotrimoxazole against Pneumocystis carinii infection $[85,89]$.

The next common non-infectious complication of HSCT is hepatic VOD, which is caused either due to the damage of hepatocytes itself or the hepatic endothelium [90]. The risk factors include pre-treatment with regimens containing busulphan, existing liver disease, previous liver radiation, unrelated donor transplant, and the use of amphotericin, methotrexate, or acyclovir in the peri-transplantation period [91]. The clinical features include new-onset ascites, jaundice, right upper quadrant pain, sudden weight gain, and oedema within the first 6 weeks of HSCT. The diagnosis is made by laboratory tests and ultrasound of the liver, which show a reversal of venous flow or portal venous thrombosis [90]. Patients with severe disease may present with liver cell failure, coagulopathy, encephalopathy, and cardiac failure. Treatment is mainly supportive because $70 \%$ of patients recover spontaneously [88].

\section{Malignant spinal cord compression}

About $6 \%$ of patients with malignancy are expected to have malignant spinal cord compression (MSCC) during the course of their illness [92]. In most cases, spinal cord compression is caused by extra- 
dural metastases from tumours involving the spine. Although most cancers can cause MSCC the most common ones are lung, breast, and prostate cancer [93]. The most common location for metastases is the thoracic spine, followed by the lumbar spine and cervical spine [94]. The most common symptoms of spinal cord compression due to vertebral metastasis are localised back pain and tenderness. These symptoms may present early, even before the diagnosis of MSCC or other neurological symptoms.

The MRI is the diagnostic method of choice. When MRI is contraindicated or unavailable, CT with or without myelography can be used [95]. The aim of treatment of MSCC is to relieve pain and to maintain or restore neurological function. If there is a delay in diagnosis, suspected cases are treated with high doses of corticosteroids - mainly dexamethasone [96] The mainstay of treatment is radiotherapy, surgical decompression, corticosteroids, or a combination of these.

\section{Superior vena cava syndrome}

Superior vena cava (SVC) syndrome occurs in the setting of extrinsic compression of SVC or occlusion of SVC. Most commonly caused by thoracic malignant tumours [97]. Lung cancer is the most common cause followed by NHL. It causes a severe reduction in venous return flow from the head, neck, and upper extremities [98]. Common symptoms include dyspnoea, orthopnoea, cough, and the sensation of fullness in the head and face, and the most common physical findings are facial and neck swelling, arm swelling, and dilated veins in the chest. Stridor and mental status changes are symptoms of advanced disease.

The CT with intravenous contrast is the most useful test for diagnosis. The MRI can be useful if contrast is contraindicated [97, 99]. Endovascular stenting of the SVC and radiation therapy are most commonly used to relieve SVC syndrome [100, 101].

\section{Other complications}

Anaphylactic reactions secondary to chemotherapeutic agents can sometimes cause medical emergencies. Commonly causes angioedema, urticaria, hypotension, bronchospasm, and laryngeal oedema. The most common agents implicated are L-asparaginase, taxanes, and platinum derivatives. Treatment includes assessment of airway, intravenous fluids, epinephrine, corticosteroids, and epinephrine [102].

Hypercalcaemia of malignancy is common in patients with advanced cancer and can be seen in up to $30 \%$ of patients with cancer [103]. It is most commonly associated with multiple myeloma, lung cancer (especially squamous cell cancer), renal cell carcinoma, breast cancer, NHL, and leukaemia. The most common symptoms of hypercalcaemia are lethargy, confusion, nausea, and severe hypercalcaemia, which can cause cardiac arrhythmias. Diagnosis is confirmed by measuring the serum calcium levels, although measurement of ionised calcium levels is the preferred method if available. Treatment is with IV fluids, calcitonin, pamidronate, zoledronic acid, or denosumab [104].

Brain metastasis is a frequent complication of cancer. Lung cancer, breast cancer, and melanoma are the most common tumours that metastasise to the brain. This can lead to increased intracranial pressure (ICP) [105]. Clinical signs and symptoms of brain metastasis are a headache, nausea, vomiting, seizures, behavioural changes, mental status changes, cerebral vascular accident, and neurological changes. The mass effect from the tumour or surrounding oedema may lead to herniation syndromes, depending on the area of the brain involved. Diagnosis can be made with the help of a CT scan or MRI of the brain [106]. If clinical suspicion of increased ICP is high, then treatment should be given before imaging studies are done. Emergency treatment to prevent brain herniation is hyperventilation, mannitol, and steroids (dexamethasone) [107]. Other treatment options include whole brain irradiation (for multiple brain metastasis), surgery plus radiation for single brain metastasis, and radiosurgery for less than three or four metastatic lesions in the brain [108].

\section{Conclusions}

Oncologic emergencies and related complications demand increased attention from attending physicians, oncologists, and intensivists. The emergencies encountered in clinical practice might also be a sign or symptom of a previously undiagnosed neoplasm. Knowledge of oncologic emergencies encountered in clinical practice expedites the ability of physicians to manage them properly. The identification and institution of proper management can improve outcomes in these patients.

\section{Conflict of interest}

The authors declare no conflict of interest.

\section{References}

1. Bray F, Ferlay J, Soerjomataram I, Siegel RL, Torre LA, Jemal A. Global cancer statistics 2018: GLOBOCAN estimates of incidence and mortality worldwide for 36 cancers in 185 countries. CA Cancer J Clin 2018; 68: 394-424.

2. Rawla P, Sunkara T, Muralidharan P, Raj JP. Update in global trends and aetiology of hepatocellular carcinoma. Contemp Oncol (Pozn) 2018; 22: 141-150.

3. Rawla P, Barsouk A. Epidemiology of gastric cancer: global trends, risk factors and prevention. Gastroenterology Rev 2019; 14: 26-38.

4. Lewis MA, Hendrickson AW, Moynihan TJ. Oncologic emergencies: pathophysiology, presentation, diagnosis, and treatment. CA Cancer J Clin 2011; 61: 287-314.

5. Howard SC, Jones DP, Pui CH. The tumor lysis syndrome. N Engl J Med 2011; 364: 1844-1854. 
6. Cairo MS, Bishop M. Tumour lysis syndrome: new therapeutic strategies and classification. Br J Haematol 2004; 127: 3-11.

7. Rampello E, Fricia T, Malaguarnera M. The management of tumor lysis syndrome. Nat Clin Pract Oncol 2006; 3: 438-447.

8. Coiffier B, Riouffol C. Management of tumor lysis syndrome in adults. Expert Rev Anticancer Ther 2007; 7: 233-239.

9. Coiffier B, Altman A, Pui CH, Younes A, Cairo MS. Guidelines for the management of pediatric and adult tumor lysis syndrome: an evidence-based review. J Clin Oncol 2008; 26: 2767-2778.

10. Rawla P, Bandaru SS, Vellipuram AR. Review of infectious etiology of acute pancreatitis. Gastroenterology Res 2017; 10: 153-158.

11. Grewal J, Grewal HK, Forman AD. Seizures and epilepsy in cancer: etiologies, evaluation, and management. Curr Oncol Rep 2008; 10: 63-71.

12. Hauser WA, Annegers JF, Kurland LT. Incidence of epilepsy and unprovoked seizures in Rochester, Minnesota: 1935-1984. Epilepsia 1993; 34: 453-458.

13. Avila EK, Graber J. Seizures and epilepsy in cancer patients. Curr Neurol Neurosci Rep 2010; 10: 60-67.

14. Tremont-Lukats IW, Armstrong T, Giglio P, Gilbert MR. Antiepileptic drugs for preventing seizures in people with brain tumors. Cochrane Database Syst Rev 2008; 2: CD004424.

15. Lin AL, Avila EK. Neurologic emergencies in the patients with cancer. J Intensive Care Med 2017; 32: 99-115.

16. Lowenstein DH, Alldredge BK. Status epilepticus. N Engl J Med 1998; 338: 970-976.

17. Treiman DM, Meyers PD, Walton NY, Collins JF, Colling C, Rowan AJ, Handforth A, Faught E, Calabrese VP, Uthman BM, Ramsay RE, Mamdani MB. A comparison of four treatments for generalized convulsive status epilepticus. Veterans Affairs Status Epilepticus Cooperative Study Group. N Engl J Med 1998; 339: 792-798.

18. Araki T, Otsubo H, Makino Y, Elliott I, Iida K, Ochi A, Weiss SK, Chuang SH, Rutka JT, Carter Snead III O. Efficacy of dexamathasone on cerebral swelling and seizures during subdural grid EEG recording in children. Epilepsia 2006; 47: 176-180.

19. Rawla P, Sunkara T, Thandra KC, Gaduputi V. Hypertriglyceridemia-induced pancreatitis: updated review of current treatment and preventive strategies. Clin J Gastroenterol 2018; 11: 441-448.

20. Reddy PS, Curtiss EI, O’Toole JD, Shaver JA. Cardiac tamponade: hemodynamic observations in man. Circulation 1978; 58: 265-272.

21. Spodick DH. Acute cardiac tamponade. N Engl J Med 2003; 349: 684-690.

22. Sternbach G. Claude Beck: cardiac compression triads. Emerg Med 1988; 6: 417-419.

23. Kim SH, Kwak MH, Park S, Kim HJ, Lee HS, Kim MS, Lee JM, Zo JI, Ro JS, Lee JS. Clinical characteristics of malignant pericardial effusion associated with recurrence and survival. Cancer Res Treat 2010; 42: 210-216.

24. Abdelsalam M, Moritz TA, Snyder JA, Cheriyath P, Spizzieri CL. Paradoxical hemodynamic instability complicating pericardial window surgery for cardiac tamponade in a cancer patient. Tex Heart Inst J 2012; 39: 711-713.
25. Papanikolaou J, Platogiannis N, Platogiannis D. Intrapericardial cisplatin instillation in recurrent postinfarction cardiac tamponade. J Cardiothorac Vasc Anesth 2018; 32: 458-460.

26. Al-Habbaa A, Rawla P, Morra ME, Abotaha AA, Sakr EE, Abdo Shehata MA, Shahin KM, Abdel Mageed S, Huy NT. Valvular involvement in granulomatosis with polyangiitis: case report and systematic review of literature. Echocardiography 2018; 35: 1456-1463.

27. Porcu P, Cripe LD, Ng EW, Bhatia S, Danielson CM, Orazi A, McCarthy LJ. Hyperleukocytic leukemias and leukostasis: a review of pathophysiology, clinical presentation and management. Leuk Lymphoma 2000; 39: 1-18.

28. Jain R, Bansal D, Marwaha RK. Hyperleukocytosis: emergency management. Indian J Pediatr 2013; 80: 144-148.

29. Gong J, Wu B, Guo T, Zhou S, He B, Peng X. Hyperleukocytosis: a report of five cases and review of the literature. Oncol Lett 2014; 8: 1825-1827.

30. Inaba H, Fan Y, Pounds S, Geiger TL, Rubnitz JE, Ribeiro $\mathrm{RC}$, Pui $\mathrm{CH}$, Razzouk BI. Clinical and biologic features and treatment outcome of children with newly diagnosed acute myeloid leukemia and hyperleukocytosis. Cancer 2008; 113: 522-529.

31. Haase R, Merkel N, Diwan O, Elsner K, Kramm CM. Leukapheresis and exchange transfusion in children with acute leukemia and hyperleukocytosis. A single center experience. Klin Padiatr 2009; 221: 374-378.

32. Chang MC, Chen TY, Tang JL, Lan YJ, Chao TY, Chiu CF, Ho HT. Leukapheresis and cranial irradiation in patients with hyperleukocytic acute myeloid leukemia: no impact on early mortality and intracranial hemorrhage. Am J Hematol 2007; 82: 976-980.

33. Korkmaz S. The management of hyperleukocytosis in 2017: do we still need leukapheresis? Transfus Apher Sci 2018; 57: 4-7.

34. van der Wekken LC, Loffeld R. Subacute disseminated intravascular coagulation in a patient with liver metastases of a renal cell carcinoma. Case Rep Oncol Med 2017; 2017: 1023538.

35. Levi M, Toh $\mathrm{CH}$, Thachil J, Watson HG. Guidelines for the diagnosis and management of disseminated intravascular coagulation. British Committee for Standards in Haematology. Br J Haematol 2009; 145: 24-33.

36. Taylor FB Jr, Toh CH, Hoots WK, Wada H, Levi M; Scientific Subcommittee on Disseminated Intravascular Coagulation (DIC) of the International Society on Thrombosis and Haemostasis (ISTH). Towards definition, clinical and laboratory criteria, and a scoring system for disseminated intravascular coagulation. Thromb Haemost 2001; 86: 1327-1330.

37. Rawla P, Pradeep Raj J, Thandra KC, Bandaru SS. Superior mesenteric vein thrombosis in a patient on oral contraceptive pills. Gastroenterology Res 2017; 10: 380-382.

38. Govind Babu K, Bhat GR. Cancer-associated thrombotic microangiopathy. Ecancermedicalscience 2016; 10: 649.

39. Moake JL. Thrombotic microangiopathies. N Engl J Med 2002; 347: 589-600.

40. Lechner K, Obermeier HL. Cancer-related microangiopathic hemolytic anemia: clinical and laboratory features in 168 reported cases. Medicine (Baltimore) 2012; 91: 195-205.

41. Freifeld AG, Bow EJ, Sepkowitz KA, Boeckh MJ, Ito JI, Mullen CA, Raad II, Rolston KV, Young JA, Wingard JR; 
Infectious Diseases Society of America. Clinical practice guideline for the use of antimicrobial agents in neutropenic patients with cancer: 2010 update by the Infectious Diseases Society of America. Clin Infect Dis 2011; 52: e56-93.

42. Halfdanarson TR, Hogan WJ, Moynihan TJ. Oncologic emergencies: diagnosis and treatment. Mayo Clin Proc 2006; 81: 835-848.

43. Lyman GH, Kuderer NM, Crawford J, Wolff DA, Culakova E, Poniewierski MS, Dale DC. Predicting individual risk of neutropenic complications in patients receiving cancer chemotherapy. Cancer 2011; 117: 1917-1927.

44. Rawla P, Vellipuram AR, Bandaru SS, Pradeep Raj J. Colon carcinoma presenting as streptococcus anginosus bacteremia and liver abscess. Gastroenterology Res 2017; 10: 376-379.

45. Kanamaru A, Tatsumi Y. Microbiological data for patients with febrile neutropenia. Clin Infect Dis 2004; 39 Suppl 1: S7-S10.

46. Rawla P, Vellipuram AR, Bandaru SS, Pradeep Raj J. Euglycemic diabetic ketoacidosis: a diagnostic and therapeutic dilemma. Endocrinol Diabetes Metab Case Rep 2017; 2017: pii: 17-0081. doi: 10.1530/EDM-17-0081.

47. Raad I, Kassar R, Ghannam D, Chaftari AM, Hachem R, Jiang Y. Management of the catheter in documented catheter-related coagulase-negative staphylococcal bacteremia: remove or retain? Clin Infect Dis 2009; 49: 1187 1194.

48. Smith TJ, Khatcheressian J, Lyman GH, Ozer H, Armitage JO, Balducci L, Bennett CL, Cantor SB, Crawford J, Cross SJ, Demetri G, Desch CE, Pizzo PA, Schiffer CA, Schwartzberg L, Somerfield MR, Somlo G, Wade JC, Wade JL, Winn RJ, Wozniak AJ, Wolff AC. 2006 update of recommendations for the use of white blood cell growth factors: an evidence-based clinical practice guideline. J Clin Oncol 2006; 24: 3187-3205.

49. Silverstein MD, Heit JA, Mohr DN, Petterson TM, O'Fallon WM, Melton LJ 3rd. Trends in the incidence of deep vein thrombosis and pulmonary embolism: a 25-year population-based study. Arch Intern Med 1998; 158: 585-593.

50. British Thoracic Society Standards of Care Committee Pulmonary Embolism Guideline Development G. British Thoracic Society guidelines for the management of suspected acute pulmonary embolism. Thorax 2003; 58: 470-483.

51. Rawla P, Vellipuram AR, Bandaru SS, Raj JP. Splenic infarct and pulmonary embolism as a rare manifestation of cytomegalovirus infection. Case Rep Hematol 2017; 2017: 1850821.

52. Blom JW, Doggen CJ, Osanto S, Rosendaal FR. Malignancies, prothrombotic mutations, and the risk of venous thrombosis. JAMA 2005; 293: 715-722.

53. Goldhaber SZ, Bounameaux H. Pulmonary embolism and deep vein thrombosis. Lancet 2012; 379: 1835-1846.

54. Miniati M, Prediletto R, Formichi B, Marini C, Di Ricco G, Tonelli L, Allescia G, Pistolesi M. Accuracy of clinical assessment in the diagnosis of pulmonary embolism. Am J Respir Crit Care Med 1999; 159: 864-871.

55. Konstantinides SV, Torbicki A, Agnelli G, Danchin N, Fitzmaurice D, Galiè N, Gibbs JS, Huisman MV, Humbert M, Kucher N, Lang I, Lankeit M, Lekakis J, Maack C, Mayer E, Meneveau N, Perrier A, Pruszczyk P, Rasmussen LH,
Schindler TH, Svitil P, Vonk Noordegraaf A, Zamorano JL, Zompatori M; Task Force for the Diagnosis and Management of Acute Pulmonary Embolism of the European Society of Cardiology (ESC). 2014 ESC guidelines on the diagnosis and management of acute pulmonary embolism. Eur Heart J 2014; 35: 3033-3069, 3069a-3069k.

56. Busse LW, Vourlekis JS. Submassive pulmonary embolism. Crit Care Clin 2014; 30: 447-473.

57. Belohlavek J, Dytrych V, Linhart A. Pulmonary embolism, part I: epidemiology, risk factors and risk stratification, pathophysiology, clinical presentation, diagnosis and nonthrombotic pulmonary embolism. Exp Clin Cardiol 2013; 18: 129-138.

58. Ibrahim WH. Massive haemoptysis: the definition should be revised. Eur Respir J 2008; 32: 1131-1132.

59. Ashraf O. Hemoptysis, a developing world perspective. BMC Pulm Med 2006; 6: 1.

60. Jean-Baptiste E. Clinical assessment and management of massive hemoptysis. Crit Care Med 2000; 28: 1642-1647.

61. Larici AR, Franchi P, Occhipinti M, Contegiacomo A, del Ciello A, Calandriello L, Storto ML, Marano R, Bonomo L. Diagnosis and management of hemoptysis. Diagn Interv Radiol 2014; 20: 299-309.

62. Yoon W, Kim JK, Kim YH, Chung TW, Kang HK. Bronchial and nonbronchial systemic artery embolization for life-threatening hemoptysis: a comprehensive review. Radiographics 2002; 22: 1395-1409.

63. Park MS. Diffuse alveolar hemorrhage. Tuberc Respir Dis (Seoul) 2013; 74: 151-162.

64. Collard HR, Schwarz MI. Diffuse alveolar hemorrhage. Clin Chest Med 2004; 25: 583-592, vii.

65. Lara AR, Schwarz MI. Diffuse alveolar hemorrhage. Chest 2010; 137: 1164-1171.

66. Swenson KK, Rose MA, Ritz L, Murray CL, Adlis SA. Recognition and evaluation of oncology-related symptoms in the emergency department. Ann Emerg Med 1995; 26: 12-17.

67. Shah J, Sunkara T, Yarlagadda KS, Rawla P, Gaduputi V. Gastric outlet and duodenal obstruction as a complication of migrated gastrostomy tube: report of two cases and literature review. Gastroenterology Res 2018; 11: 71-74.

68. Scott-Conner CE, Fabrega AJ. Gastrointestinal problems in the immunocompromised host. A review for surgeons. Surg Endosc 1996; 10: 959-964.

69. Ilgen JS, Marr AL. Cancer emergencies: the acute abdomen. Emerg Med Clin North Am 2009; 27: 381-399.

70. Rice AD, Patterson K, Reed ED, Wurn BF, Klingenberg B, King III CR, Wurn LJ. Treating small bowel obstruction with a manual physical therapy: a prospective efficacy study. Biomed Res Int 2016; 2016: 7610387.

71. Ratajczak P, Serafin Z, Sławińska A, Słupski M, Leszczyński W. Improved imaging of colorectal liver metastases using single-source fast $\mathrm{kVp}$-switching dual-energy $\mathrm{CT}$ : preliminary results. Pol J Radiol 2018; 83: 514-520.

72. Nishii T, Rino Y, Ando K, Matsuzu K, Wada H, Chiba A, Arai H, Ashida A, Hasuo K, Inayama Y, Takanashi Y. Successful treatment of multiple small-bowel perforations caused by cytomegalovirus in a patient with malignant lymphoma: report of a case. Surg Today 2006; 36: 930-933.

73. Rawla P, Raj JP. Doxycycline-induced acute pancreatitis: a rare adverse event. Gastroenterology Res 2017; 10: 244246. 
74. Cotton M. The acute abdomen and HIV. Trop Doct 2006; 36: $198-200$.

75. van Leerdam ME. Epidemiology of acute upper gastrointestinal bleeding. Best Pract Res Clin Gastroenterol 2008; 22: 209-224.

76. Yarris JP, Warden CR. Gastrointestinal bleeding in the cancer patient. Emerg Med Clin North Am 2009; 27: 363-379.

77. Cuellar RE, Gavaler JS, Alexander JA, Brouillette DE, Chien MC, Yoo YK, Rabinovitz M, Stone BG, Van ThielDH Gastrointestinal tract hemorrhage. The value of a nasogastric aspirate. Arch Intern Med 1990; 150: 1381-1384.

78. Maltz GS, Siegel JE, Carson JL. Hematologic management of gastrointestinal bleeding. Gastroenterol Clin North Am 2000; 29: 169-187, vii.

79. Rawla P, Sunkara T, Thandra KC, Gaduputi V. Efficacy and safety of budesonide in the treatment of eosinophilic esophagitis: updated systematic review and metaanalysis of randomized and non-randomized studies. Drugs R D 2018; 18: 259-269.

80. Komarnicka J, Brzewski M, Banaszkiewicz A, Maciąg R, Krysiak R. Computed tomography (CT) angiography in pre-embolization assessment of location of gastrointestinal bleeding in paediatric patient with granulomatosis with polyangiitis (Wegener's granulomatosis) - case report. Pol J Radiol 2018; 82: 589-592.

81. Eisen GM, Dominitz JA, Faigel DO, Goldstein JL, Kalloo AN, Petersen BT, Raddawi HM, Ryan ME, Vargo JJ $3^{\text {rd }}$, Young HS, Fanelli RD, Hyman NH, Wheeler-Harbaugh J; American Society for Gastrointestinal Endoscopy. Standards of Practice Committee. An annotated algorithmic approach to upper gastrointestinal bleeding. Gastrointest Endosc 2001; 53: 853-858.

82. Omari J, Heinze C, Wilck A, Hass P, Seidensticker M, Damm R, Fischbach K, Ricke J, Pech M, Powerski M. Image-guided interstitial high-dose-rate brachytherapy in the treatment of metastatic esophageal squamous cell carcinoma. J Contemp Brachyther 2018; 10: 439-445.

83. Coleman RE. Skeletal complications of malignancy. Cancer 1997; 80: 1588-1594

84. Autorino R, Vicenzi L, Tagliaferri L, Soatti C, Kovacs G, Aristei C. A national survey of AIRO (Italian Association of Radiation Oncology) brachytherapy (Interventional Radiotherapy) study group. J Contemp Brachyther 2018; 10: 254-259.

85. Adelberg DE, Bishop MR. Emergencies related to cancer chemotherapy and hematopoietic stem cell transplantation. Emerg Med Clin North Am 2009; 27: 311-331.

86. Couriel D, Caldera H, Champlin R, Komanduri K. Acute graft-versus-host disease: pathophysiology, clinical manifestations, and management. Cancer 2004; 101: 1936-1946.

87. Schwartz JM, Strasser SI, Lopez-Cubero SO, Murakami CS, Hockenbery DM, McDonald GB. Severe gastrointestinal bleeding after marrow transplantion, 1987-1997: incidence, causes, and outcome. Gastroenterology 1998; 114: A40.

88. Mohty B, Mohty M. Long-term complications and side effects after allogeneic hematopoietic stem cell transplantation: an update. Blood Cancer J 2011; 1: e16.

89. Sunkara T, Rawla P, Ofosu A, Gaduputi V. Fecal microbiota transplant - a new frontier in inflammatory bowel disease. J Inflamm Res 2018; 11: 321-328.

90. McDonald GB, Hinds MS, Fisher LD, Schoch HG, Wolford JL, Banaji M, Hardin BJ, Shulman HM, Clift RA. Ve- no-occlusive disease of the liver and multiorgan failure after bone marrow transplantation: a cohort study of 355 patients. Ann Intern Med 1993; 118: 255-267.

91. Kumar S, DeLeve LD, Kamath PS, Tefferi A. Hepatic veno-occlusive disease (sinusoidal obstruction syndrome) after hematopoietic stem cell transplantation. Mayo Clin Proc 2003; 78: 589-598.

92. Mak KS, Lee LK, Mak RH, Wang S, Pile-Spellman J, Abrahm JL, Prigerson HG, Balboni TA. Incidence and treatment patterns in hospitalizations for malignant spinal cord compression in the United States, 1998-2006. Int J Radiat Oncol Biol Phys 2011; 80: 824-831.

93. Loblaw DA, Laperriere NJ, Mackillop WJ. A populationbased study of malignant spinal cord compression in Ontario. Clin Oncol (R Coll Radiol) 2003; 15: 211-217.

94. Bach F, Larsen BH, Rohde K, Børgesen SE, Gjerris F, BøgeRasmussen T, Agerlin N, Rasmusson B, Stjernholm P, Sørensen PS. Metastatic spinal cord compression. Occurrence, symptoms, clinical presentations and prognosis in 398 patients with spinal cord compression. Acta Neurochir (Wien) 1990; 107: 37-43.

95. Husband DJ, Grant KA, Romaniuk CS. MRI in the diagnosis and treatment of suspected malignant spinal cord compression. Br J Radiol 2001; 74: 15-23.

96. George R, Jeba J, Ramkumar G, Chacko AG, Tharyan P. Interventions for the treatment of metastatic extradural spinal cord compression in adults. Cochrane Database Syst Rev 2015; 9: CD006716.

97. Wilson LD, Detterbeck FC, Yahalom J. Clinical practice. Superior vena cava syndrome with malignant causes. N Engl J Med 2007; 356: 1862-1869.

98. Lepper PM, Ott SR, Hoppe H, Schumann C, Stammberger U, Bugalho A, Frese S, Schmücking M, Blumstein NM, Diehm N, Bals R, Hamacher J. Superior vena cava syndrome in thoracic malignancies. Respir Care 2011; 56: 653-666.

99. Wan JF, Bezjak A. Superior vena cava syndrome. Hematol Oncol Clin North Am 2010; 24: 501-513.

100. Rachapalli V, Boucher LM. Superior vena cava syndrome: role of the interventionalist. Can Assoc Radiol J 2014; 65: 168-176.

101. Ganeshan A, Hon LQ, Warakaulle DR, Morgan R, Uberoi R. Superior vena caval stenting for SVC obstruction: current status. Eur J Radiol 2009; 71: 343-349.

102. Markman M, Kennedy A, Webster K, Kulp B, Peterson G, Belinson J. Paclitaxel-associated hypersensitivity reactions: experience of the gynecologic oncology program of the Cleveland Clinic Cancer Center. J Clin Oncol 2000; 18: 102-105.

103. Stewart AF. Clinical practice. Hypercalcemia associated with cancer. N Engl J Med 2005; 352: 373-379.

104. Davidson TG. Conventional treatment of hypercalcemia of malignancy. Am J Health Syst Pharm 2001; 58 Suppl 3: S8-15.

105. Fox BD, Cheung VJ, Patel AJ, Suki D, Rao G. Epidemiology of metastatic brain tumors. Neurosurg Clin N Am 2011; 22: 1-6, v.

106. Schaefer PW, Budzik RF Jr, Gonzalez RG. Imaging of cerebral metastases. Neurosurg Clin N Am 1996; 7: 393423.

107. Ryken TC, McDermott M, Robinson PD, Ammirati M, Andrews DW, Asher AL, Burri SH, Cobbs CS, Gaspar LE, Kondziolka D, Linskey ME, Loeffler JS, Mehta MP, Mikkelsen T, Olson JJ, Paleologos NA, Patchell RA, Kalka- 
nis SN. The role of steroids in the management of brain metastases: a systematic review and evidence-based clinical practice guideline. J Neurooncol 2010; 96: 103-114.

108. Lin X, DeAngelis LM. Treatment of brain metastases. J Clin Oncol 2015; 33: 3475-3484.

\section{Address for correspondence:}

Paul Oben MD

Department of Medicine

University of Chicago

IL, USA

E-mail: drpoben@gmail.com 